\title{
Comparative Anti-diabetic Activities of Methanol and n-Hexane Extracts of Anthocleistavogelii (Gentianaceae) Stem Bark in Normoglycemic and Alloxan-Induced Diabetic Rats
}

\author{
Onyekere Peculiar Feenna ${ }^{1 *}$, Onyeke Blessing Ugonne ${ }^{2}$, Udodeme Helen Ogechukwu ${ }^{1}$, \\ AnosikeChibuze ${ }^{3}$ \\ ${ }^{1}$ Department of Pharmacognosy and Environmental Medicines, University of Nigeria, Nigeria \\ ${ }^{2}$ Departments of Pharmaceutical and Medicinal Chemistry, University of Nigeria, Nigeria \\ ${ }^{3}$ Department of Clinical Pharmacy and Pharmacy Management, University of Nigeria, Nigeria
}

\begin{abstract}
The aim of the study was to evaluate comparatively the potential anti-diabetic activity of the methanol and n-hexane extracts of the stem bark of Anthocleista vogelii in normoglycemic and alloxan-induced diabetic rats.

The alloxan-induced diabetic rats were treated orally with $200 \mathrm{mg} / \mathrm{kg}$ and $400 \mathrm{mg} / \mathrm{kg}$ of the methanol extract $(\mathrm{ME})$ and $\mathrm{n}$-hexane extract $(\mathrm{HE}) ; 0.2 \mathrm{mg} / \mathrm{kg}$ of glibenclamide (positive control for both extracts), $2 \mathrm{~mL} / \mathrm{kg}$ of normal saline and $2 \mathrm{~mL} / \mathrm{kg}$ of olive oil (negative controls for $\mathrm{ME}$ and $\mathrm{HE}$ respectively).The normoglycemic rats received $200 \mathrm{mg} / \mathrm{kg}$ and $400 \mathrm{mg} / \mathrm{kg}$ of $\mathrm{ME}, 0.2 \mathrm{mg} / \mathrm{kg}$ of glibenclamide and $2 \mathrm{~mL} / \mathrm{kg}$ of normal saline.

The FBGL were monitored at 0, 0.5, 1, 2, 3, 4, 6 and $12 \mathrm{~h}$ for the two categories and the results were statistically analysed. The phytochemical analyses of $M E$ and HE were also carried out by standard procedures. The extracts showed statistically significant $(p<0.05)$ anti-diabetic activity. The percentage reductions of blood glucose level after $12 \mathrm{~h}$ treatment with $\mathrm{ME}$ were $83.2 \%$ (400 $\mathrm{mg} / \mathrm{kg})$ and $79.5 \%(200 \mathrm{mg} / \mathrm{kg})$ in alloxan-induced group and were higher compared to the n-hexane extract (HE); $56.5 \%$ (200 mg/kg), $43.6 \%$ (400 $\mathrm{mg} / \mathrm{kg}$ ) and the glibenclamide $75.9 \%(0.2 \mathrm{mg} / \mathrm{kg})$. In the normal rats $200 \mathrm{mg} / \mathrm{kg}$ and $400 \mathrm{mg} / \mathrm{kg}$ of $\mathrm{ME}$ gave $43.8 \%$ and $58.9 \%$ respectively compared to glibenclamide $(37.7 \%$.)

Their phytochemical analyses revealed the presence of alkaloids, tannins, flavonoids, steroids, saponins, terpenoids. The methanol extract of the stem bark of A. vogelii has greater potential hypoglycemic effects compared to $n$-hexane extract
\end{abstract}

Keywords: Anthocleistavogelii, phyto chemical analysis, hypoglycemia, alloxan, anti-diabetic

Abbreviations: FBGL-Fasting Blood Glucose Level, ME-Methanol Extract, HE-n-Hexane Extract.

\section{INTRODUCTION}

The use of medicinal plants in the prevention, treatment and management of diseases has been on the increase as well studies on their biological effects. One of such ailments that herbal remedies have been widely used to manage is that of diabetes $[1,2]$.

Diabetes is a group of metabolic diseases characterized by hyperglycemia resulting from defects in insulin secretion, insulin action, or both. Diabetes mellitus is a chronic disease caused by inherited and/or acquired deficiency in production of insulin by the pancreas, or by ineffectiveness of the insulin produced [3]. Type 1 diabetes (insulin dependent)is caused due to insulin insufficiency because of lack of functional beta cells ,patients suffering from this are therefore totally dependent on exogenous source of insulin while patients suffering from type II diabetes(insulin independent)are unable to respond to insulin and can be treated with dietary changes, exercise and medication. The more common form is the type II constituting $90 \%$ of the diabetic population [4]. Due to the increasing chronic complications of diabetes mellitus, it is postulated that by 2030 , the diabetic population would have risen to 439 million adults worldwide [5].

The search for newer hypoglycemic agents has continued to be on the rise due to the multiple side effects associated with the available synthetic ones. Medicinal plants have been known to be relatively safe and less expensive in the management of diabetes [6]. 
Anthocleista vogelii Planch is a plant of the family Gentianaceae that is common in tropical Africa, Cameroon, Sudan, and Sierra Leone. It is also found in Northern, Western and Eastern Nigeria particularly in swampy areas near streams and closed forests [7].

The different parts of $A$. vogelii have been reported to be used for the management and treatment of various diseases. For instance, the decoction of $A$. vogeliiroot is reported to be commonly taken to treat constipation and to regulate menstruation [8]. In Sierra Leone, the decoction of the root is taken to alleviate chest pain and for the treatment of hepatitis when taken with lemon. Also in Ghana, it has been reported that a root decoction of A. vogeliiand Combretummucronatumwith pepper and ashes is taken to treat chest pain [9]. In Nigeria, the bark and seed are used as an antipyretic and tonic. The acetone fraction of the methanol extract has been investigated to have significant antidiabetic activity [6] while the ethanol root extract has been investigated for anti-diabetic activity [8].

Hence the study aims at evaluating and comparing the methanol and n-hexane extract of the stem bark of A. vogelii in alloxan-induced diabetic albino rats. No known work has been carried out on the nhexane extract of the stem bark of A. vogelii as at the time of this work.

\section{MATERials AND MeTHODS}

\subsection{Chemicals/Reagents}

The solvents used were the defattening solvent, n-hexane (Kermel, USA); the extraction solvent, methanol (Sigma, USA), whole distilled water, to adjust the polarity of the methanol; and normal saline.

The chemical reagents used for the phytochemical analysis were sourced commercially and include Molishch's reagent, Fehling's solution A and B, Mayer's reagent, Benedict's reagent, Wagner's reagent, Dragendorff's reagent and Picric acid.

Other chemicals used include, Alloxan monohydrate (Sigma,USA), glibenclamide (Hovid, Nigeria). The equipment used include Citizen electronic balance (Model Mp 300, Max. 300g), rotary evaporator (Buchi-Rotavator-R, China), Steam bath, Accu- Chek® Active Glucometer and strips (MODE: GC, Roche, Germany)

\subsection{Plant Collection and Extraction}

The stem bark of the plant Anthocleista vogelli was collected during the rainy season in the month of June from Nwakpa, Calabar, Cross river state, Nigeria. The plant was identified and authenticated by Mr. Ozioko, a taxonomist of Bioresource Development and Conservative Centre (BDCC), Nsukka. It was air- dried (under shade) for two weeks and was pulverized with a grinder, sieved and stored in clean water- proof bags. The pulverized powder was weighed with an electronic balance.

A 990g of the powdered stem bark was defattened using 3 litres of $n$-hexane by cold maceration for $72 \mathrm{~h}$ at room temperature with occasional shaking. After $72 \mathrm{~h}$, the mixture was vigorously shaken in the amber- coloured air tight bottle and filtered using clean cotton wool inserted into a funnel. The oily filtrate was concentrated using a rotator evaporator (Buchi-Rotavator-R, China) under reduced pressure, at a temperature of $45^{\circ} \mathrm{C}$ to obtain the $\mathrm{n}$ - hexane extract of Anthocleista vogelli (HE).

The methanol extract (ME) was obtained by macerating the defattened sample in 5 litres of $95 \%$ methanol for $72 \mathrm{~h}$ at room temperature $\left(30 \pm 2{ }^{\circ} \mathrm{C}\right)$ with constant stirring. After filtration through a cotton wool plug, the filtrate was concentrated in vacuum $\left(40^{\circ} \mathrm{C}\right)$ using a rotary evaporator (BuchiRotavator-R, China).

\subsection{PhytochemicalAnalysis}

The phytochemical analysis was carried out on the methanol and n-hexane stem bark extracts of Anthocleista vogelli using the standard procedures [10,11]. The presence or absence of a particular phytochemical compound involved the addition of appropriate standard chemicals/reagents in appropriate sequence to the plant extracts. The following classes of phyto- chemicals were screened in both extracts: alkaloids, glycosides, carbohydrates, reducing sugars, saponins, tannins, flavonoids and steroids. 


\subsubsection{Test for Tannins}

About $0.5 \mathrm{~g}$ of the dried powdered samples was boiled in $20 \mathrm{~mL}$ of water in a test tube and then filtered. A few drops of $0.1 \%$ ferric chloride was added and observed for brownish green or a blueblack colouration.

\subsubsection{Test for Saponin}

About $2 \mathrm{~g}$ of the powdered sample was boiled in $20 \mathrm{~mL}$ of distilled water in a water bath and filtered. $10 \mathrm{~mL}$ of the filtrate was mixed with $5 \mathrm{~mL}$ of distilled water and shaken vigorously for a stable persistent froth. The frothing was mixed with 3 drops of olive oil and shaken vigorously, then observed for the formation of emulsion.

\subsubsection{Test for Flavonoids}

A portion of the powdered plant sample was heated with $10 \mathrm{~mL}$ of ethyl acetate over a steam bath for $3 \mathrm{~min}$. The mixture was filtered and $4 \mathrm{~mL}$ of the filtrate was shaken with $1 \mathrm{~mL}$ of dilute ammonia solution. A yellow colouration was observed indicating a positive test for flavonoids.

\subsubsection{Test for Carhohydrates (Molisch's test)}

A $0.1 \mathrm{~g}$ of the powder was boiled with $2 \mathrm{~mL}$ of distilled water and filtered. To the filtrate were added few drops of $\alpha$-naphthol solution in ethanol (Molisch's reagent). Concentrated sulphuric acid was then gently poured down the side of the test tube to form a lower layer. A purple interfacial ring was observed indicating the presence of carbohydrates

\subsubsection{Test for Glycosides (Combined reducing sugars)}

A $5 \mathrm{~mL}$ of dilute sulphuric acid was added to $0.1 \mathrm{~g}$ of the powder in a test tube, boiled for 15 minutes on a water bath, then cooled and neutralized with $20 \%$ potassium hydroxide solution. $10 \mathrm{~mL}$ of a mixture of equal parts of Fehling solution I and II was added and boiled for 5 minutes. A more dense brick red precipitate indicated the presence of glycosides.

\subsubsection{Test for Steriods}

A $5 \mathrm{~mL}$ of acetic anhydride was added to $0.5 \mathrm{~g}$ of the powdered sample with $2 \mathrm{~mL} \mathrm{H} 2 \mathrm{~S} 04$. The colour changed from violet to blue indicating the presence of steroids.

Test for Terpenoids (Salkowski test): Five $\mathrm{mL}$ of the extract was mixed in $2 \mathrm{~mL}$ of chloroform, and concentrated $\mathrm{H} 2 \mathrm{~S} 04(3 \mathrm{~mL})$ was carefully added to form a layer. A reddish brown colouration of the inter face was formed to show positive results for the presence of terpenoids.

\subsubsection{Test for Alkaloids}

$0.5 \mathrm{~g}$ of the powdered extracts was stirred in $5 \mathrm{~mL}$ of $1 \% \mathrm{HClaq}$ on a steam bath for 5 minutes. The mixture was then filtered using Whatman's nol filter paper. To the filtrate, 2-4drops of Dragend off's reagent was added to $1 \mathrm{~mL}$ of the filtrate. An orange-red colour was observed indicating the presence of alkaloids.

\subsubsection{Test for Reducing Sugars (Free)}

A $5 \mathrm{~mL}$ of a mixture of equal parts of Fehling's solution I and II were added to $5 \mathrm{~mL}$ of aqueous extract and then heated on a water bath for 5 minutes. A brick red precipitate showed the presence of reducing sugar. .

\subsubsection{Test for Acidic Compounds}

A $0.1 \mathrm{~g}$ of the powder was placed in a clear dry test tube and sufficient water added. This was warmed on a hot water bath and then cooled. The piece of water wetted litmus paper was dipped into the filtrate and the colour change on the litmus paper from blue to red was observed.

\subsection{Animals}

Albino rats weighing 150-200 g of both sexes were used for the studies. The animals were procured from the animal house of the Faculty of Veterinary Medicine, University of Nigeria, Nsukka. They were kept in well ventilated aluminum cages at room temperature in the animal house of Department of Pharmacology and Toxicology, University of Nigeria, Nsukka. They were fed with Top feed and 
allowed to drink water ad libitum. The animals were allowed to acclimatize for seven days before being used for the studies.

\section{HYPOGLYCEMIC STUDIES}

\subsection{Determination of Hypoglycemic Effect on Normoglycemic Rats}

Sixteen healthy rats weighing 130-180 g were used for this experiment. The animals were divided into four groups each containing four animals. They were fasted overnight for $12 \mathrm{~h}$ but allowed free access to water during and throughout the experiment. At the end of the fasting period, different doses of the extract were given to the animals via the oral route. They were treated in this order Group 1:2 mL/kg of normal saline (negative control); Group 2: $0.2 \mathrm{mg} / \mathrm{kg}$ of glibenclamide (positive control); Group 3: $200 \mathrm{mg} / \mathrm{kg}$ of ME of A. vogelli; Group 4: $400 \mathrm{mg} / \mathrm{kg}$ of ME of A. vogelii. Following the oral administration as outlined above, blood samples were taken from the tail veins of the rats. Their blood glucose concentrations were determined at $0,0.5,1,2,3,4,6$ and $12 \mathrm{~h}$ interval, using the AccuChek ${ }^{\circledR}$ Active Roche glucometer

\subsection{Determination of Hypoglycemic Effect on Alloxan-Induced Diabetic Rats}

The rats were fasted for $12 \mathrm{~h}$ and diabetes was induced by a single intraperitoneal injection (i.p.) of freshly prepared solution of alloxan monohydrate $150 \mathrm{mg} / \mathrm{kg}$. Then $72 \mathrm{~h}$ later rats with Fasting Blood Glucose Levels (FBGL) above $200 \mathrm{mg} / \mathrm{dL}$ were considered diabetic and selected for the experiment $[12,13]$.

\subsection{Using the Methanol Extract (ME)}

The diabetic animals were selected and placed into four groups of four animals each. Group 1 receieved: $2 \mathrm{~mL} / \mathrm{kg}$ of normal saline (positive control); Group 2 received $0.2 \mathrm{mg} / \mathrm{kg}$ of Glibenclamide; Group 3: $200 \mathrm{mg} / \mathrm{kg}$ of ME of A. vogelii; Group 4: $400 \mathrm{mg} / \mathrm{kg}$ of ME of A. vogelii. All were administered via the oral route.

\subsection{Using the n-Hexane Extract (HE)}

The diabetic rats were selected and placed into three groups. The n-hexane extract of Anthocleista vogelii at doses of $200 \mathrm{mg} / \mathrm{kg}$ and $400 \mathrm{mg} / \mathrm{kg}$ all dissolved in the vehicle (olive oil) were given orally to the animals which served as group 5 and 6 respectively for the experiment. Also olive oil at a dose of $2 \mathrm{~mL} / \mathrm{kg}$ was administered to the last group which served as the negative control for the $\mathrm{n}$-hexane extract.

Group 5: $200 \mathrm{mg} / \mathrm{kg}$ of HE of A. vogelii (p.o)

Group 6: $400 \mathrm{mg} / \mathrm{kg}$ of HE of A. vogelii (p.o)

Group 7: $2 \mathrm{~mL} / \mathrm{kg}$ of olive oil. (p.o)

Blood samples were collected from the tail vein of the rats under mild anesthesia. Then the blood glucose concentrations were monitored up to the 12th hour post administration of the various treatments as stated above.

\subsection{Stastical Analysis}

The results from the experiment were expressed as the mean values for each group (i.e. mean blood glucose concentrations in milligram per $100 \mathrm{~mL}) \pm$ Standard Error of Mean (SEM). The results were analysed by the statistical package (SPSS 16.0) One Way Analysis of Variance (ANOVA) method, with Dunnet test for multiple comparisons compared to the control.

Blood glucose concentrations at $\mathrm{P}<0.05$ and $\mathrm{P}<0.01$ were considered significant compared to the control [6].

\section{RESUltS}

\subsection{Extraction Yield}

The yield of ME was $1.40 \%$ while that of HE was $0.17 \%$ after extraction as can be seen in Table 1 .

Table 1. The different percentage extraction yield of the two different solvents.

\begin{tabular}{|l|l|l|l|l|}
\hline Solvent & Weight of sample(g) & Weight of Extract $(\mathbf{g})$ & Yield(g) & \% Yield \\
\hline Methanol & 990.93 & 13.91 & 0.01403 & 1.403 \\
\hline n- Hexane & 990.93 & 1.70 & 0.00172 & 0.172 \\
\hline
\end{tabular}


Comparative Anti-diabetic Activities of Methanol and n-Hexane Extracts of Antho cleistavogelii (Gentianaceae) Stem Bark in Normo glycemic and Alloxan-Induced Diabetic Rats

\subsection{Phytochemical Analysis}

The phytochemical analysis of both extracts (ME \& HE) revealed the presence of carbohydrates, alkaloids, tannins, flavonoids, steroids, saponins, terpenoids, resins and oils in varied proportions. Glycosides were only present in the methanol extract. Proteins, reducing sugar and acidic compounds were absent in both extracts (Table 2).

Table 2.Phytochemical constituents of Anthocleistavogelii.

\begin{tabular}{|c|c|c|c|}
\hline $\mathbf{S} / \mathbf{N}$ & Tests & Methanolic Extract & n-Hexane Extract \\
\hline 1 & Carbohydrate & ++ & ++ \\
\hline 2 & Reducing sugar & - & + \\
\hline 3 & Alkaloids & +++ & - \\
\hline 4 & Glycosides & +++ & ++ \\
\hline 5 & Saponins & +++ & ++ \\
\hline 6 & Tannins & +++ & ++ \\
\hline 7 & Flavonoids & +++ & - \\
\hline 8 & Resins & - & ++ \\
\hline 9 & Proteins & ++ & ++ \\
\hline 10 & Oil & + & + \\
\hline 11 & Steroids & +++ & - \\
\hline 12 & Terpenoids & - & \\
\hline 13 & Acidic compounds & & + \\
\hline
\end{tabular}

KEY:-=Absent, +=Present, ++= Moderately present,$+++=$ Abundantly present .

\subsection{Effect of Methanol Extract (ME) of A. Vogelii on Normoglycemic Rats}

The result of the effect of ME in the normoglycemic rats showed a dose-dependent reduction in blood glucose concentration. (Table3). At a dose of $400 \mathrm{mg} / \mathrm{kg}$ of ME, $58.9 \%$ glibenclamide (37.7 \%) and 2 $\mathrm{ml} / \mathrm{kg}$ of normal saline (23.9\%), At $\mathrm{p}<0.05$, significant reductions were noted for the $200 \mathrm{mg} / \mathrm{kg}$ of $\mathrm{ME}$ at $0.5,1,2,3,6$ and 12 hours respectively, while for $400 \mathrm{mg} / \mathrm{kg}$ of ME, significant reduction was noted at 3 and 12 hours respectively compared with normal saline (negative control).At $p<0.01$, there were no significant reductions in blood glucose concentrations for the two doses of ME.

Table3. Effect of Methanol Extract (ME) of stem bark of A.vogelli in Normoglycemic rats.

Fasting Blood Glucose Concentration (mg/dl)

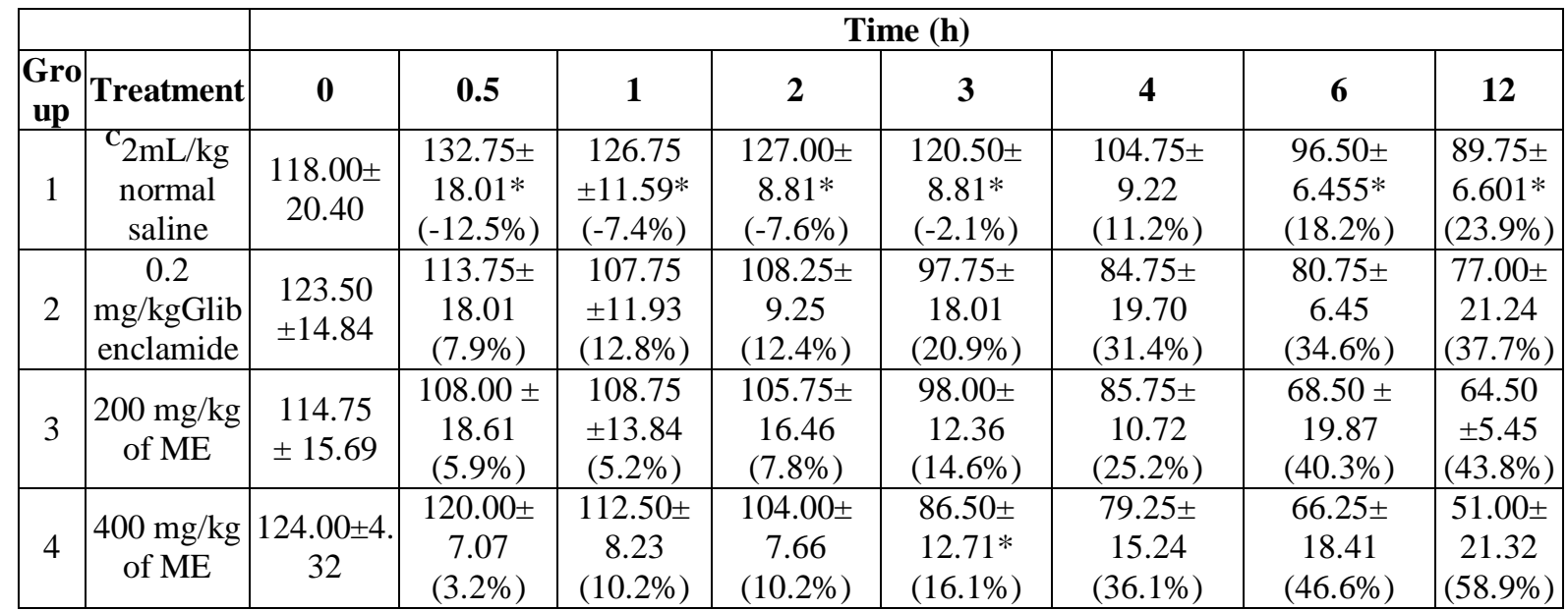

c: Control group; Results are expressed as mean \pm SEM $(n=4) ; * p<0.05, * * p<0.01$ as compared with control group at the same time. One-way, ANOVA followed by Dunnet's t-test; Figures in parenthesis denote percentage reduction of blood glucose.

\subsection{Effect of Methanol Extract (ME) of A. vogelli in Alloxan-induced Diabetic rats}

The result of the anti-diabetic effect of methanol extract (ME) in the alloxan-induced diabetic rats showed a dose-dependent reduction in blood glucose concentration (Table 4).

The two doses of ME (200 mg/kg and $400 \mathrm{mg} / \mathrm{kg}$ ) had their onset of action (reduction in blood glucose level) at $0.5 \mathrm{~h}$ and peaked at the $12 \mathrm{th} \mathrm{h}$. For the $400 \mathrm{mg} / \mathrm{kg}$ dose of ME, there was a consistent 
decrease in blood glucose concentration from 0.5 to the 12 th $\mathrm{h}$. This was the same for the $200 \mathrm{mg} / \mathrm{kg}$ of ME except at the 6th $\mathrm{h}$.

Percentage reduction in blood glucose concentration was highest in the $400 \mathrm{mg} / \mathrm{kg}$ of ME $(83.2 \%)$, followed by the $200 \mathrm{mg} / \mathrm{kg}$ of $\mathrm{ME}(79.5 \%)$; compared to the positive control $(0.2 \mathrm{mg} / \mathrm{kg}$ gliben clamide) and negative control $2 \mathrm{~mL} / \mathrm{kg}$ (normal saline) which were $75.85 \%$ and $30.2 \%$ respectively.

Highly significant activities (at $\mathrm{p}<0.01$ ) were noted in both doses of ME at $0.5,1,2,3$ and $4 \mathrm{~h}$ respectively. However anti-diabetic activity was noted from the 3rd to 12th hour for the controls respectively.

Table 4. Effect of Methanol Extract (ME) of A. vogelli in Alloxan-induced Diabetic rats.

Fasting Blood Glucose Concentration (mg/dl)

\begin{tabular}{|c|c|c|c|c|c|c|c|c|c|}
\hline Group & Treatment & $0 \mathrm{~h}$ & $0.5 \mathrm{~h}$ & $1 \mathrm{~h}$ & $2 \mathrm{~h}$ & $3 \mathrm{~h}$ & $4 \mathrm{~h}$ & $6 \mathrm{~h}$ & $12 \mathrm{~h}$ \\
\hline 1 & $\begin{array}{c}\mathrm{C}_{2 \mathrm{~mL} / \mathrm{kg}} \\
\text { normalSaline }\end{array}$ & $\begin{array}{c}473.75 \pm \\
80.94\end{array}$ & $\begin{array}{c}467.25 \pm \\
78.92 \\
(1.37 \%)\end{array}$ & $\begin{array}{c}447.50 \pm \\
69.09 \\
(5.5 \%)\end{array}$ & $\begin{array}{c}434.00 \pm \\
68.93 \\
(8.4 \%)\end{array}$ & $\begin{array}{c}425.50 \pm \\
68.96 * \\
(10.2 \%)\end{array}$ & $\begin{array}{c}395.00 \pm \\
87.57 * \\
(16.6 \%)\end{array}$ & $\begin{array}{c}367.75 \pm \\
91.20 * \\
(23.4 \%)\end{array}$ & $\begin{array}{c}330.25 \pm \\
84.00 * \\
(30.3 \%)\end{array}$ \\
\hline 2 & $\begin{array}{c}0.2 \mathrm{mg} / \mathrm{kg} \\
\text { glibenclamide }\end{array}$ & $\begin{array}{c}424.50 \pm \\
41.48\end{array}$ & $\begin{array}{c}418.75 \pm \\
41.60 \\
(1.4 \%)\end{array}$ & $\begin{array}{c}398.50 \pm \\
40.07 \\
(6.1 \%)\end{array}$ & $\begin{array}{c}330.50 \pm \\
32.63 \\
(22.1 \%)\end{array}$ & $\begin{array}{c}278.25 \pm \\
23.74 * \\
(34.5 \%)\end{array}$ & $\begin{array}{c}241.50 \pm \\
28.24 * \\
(43.1 \%)\end{array}$ & $\begin{array}{c}194.25 \pm \\
30.35 * \\
(54.2 \%)\end{array}$ & $\begin{array}{c}102.50 \pm \\
35.70 * \\
(75.9 \%)\end{array}$ \\
\hline 3 & $\begin{array}{c}200 \mathrm{mg} / \mathrm{kg} \text { of } \\
\mathrm{ME}\end{array}$ & $\begin{array}{c}488.75 \pm \\
32.84\end{array}$ & $\begin{array}{c}217.00 \pm \\
84.52 * \\
(55.6 \%)\end{array}$ & $\begin{array}{c}198.50 \pm \\
3.45^{*} \\
(59.4 \%)\end{array}$ & $\begin{array}{c}175.75 \pm \\
93.33 * \\
(64.0 \%)\end{array}$ & $\begin{array}{c}149.25 \pm \\
81.19 * \\
(69.5 \%)\end{array}$ & $\begin{array}{c}111.75 \pm \\
54.35 * \\
(77.1 \%)\end{array}$ & $\begin{array}{c}208.25 \pm \\
113 . \\
(57.4 \%)\end{array}$ & $\begin{array}{c}100.25 \pm \\
43.56 \\
(79.5 \%)\end{array}$ \\
\hline 4 & $\begin{array}{c}400 \mathrm{mg} / \mathrm{kg} \text { of } \\
\mathrm{ME}\end{array}$ & $\begin{array}{l}326.25 \pm \\
41.56 * *\end{array}$ & $\begin{array}{l}186.75 \pm \\
102.02 * \\
(42.8 \%)\end{array}$ & $\begin{array}{l}191.25 \pm \\
121.93^{*} \\
(41.4 \%)\end{array}$ & $\begin{array}{c}156.75 \pm \\
82.76 * \\
(51.9 \%)\end{array}$ & $\begin{array}{c}124.25 \pm \\
58.44 * \\
(61.9 \%)\end{array}$ & $\begin{array}{c}117.75 \pm \\
36.79 * \\
(63.9 \%)\end{array}$ & $\begin{array}{c}96.25 \pm \\
41.98 \\
(70.5 \%)\end{array}$ & $\begin{array}{c}54.75 \pm \\
16.520 \\
(83.2 \%)\end{array}$ \\
\hline
\end{tabular}

c: Control group; Results are expressed as mean \pm SEM $(n=4) ;{ }^{*} p<0.05,{ }^{* *} p<0.01$ as compared with control group at the same time. One-way, ANOVA followed by Dunnet's t-test; Figures in parenthesis denote percentage reduction of blood glucose.

\subsection{Effect of N-Hexane Extract (HE) Of A. Vogelli in Alloxan Induced Diabetic Rats}

The result of the anti-diabetic effect of n-hexane extract (HE) in alloxan-induced diabetic rats showed a non dose dependent reduction in blood glucose concentration ( Table 5).

The mean percentage reduction in blood glucose concentration was highest in $200 \mathrm{mg} / \mathrm{kg}$ of $\mathrm{HE}$ (56.5\%) followed by the $400 \mathrm{mg} / \mathrm{kg} \mathrm{HE}(43.6 \%)$ and the least was $2 \mathrm{~mL} / \mathrm{kg}$ of olive oil $(6.52 \%)$ which served as the negative control. Also the percentage reductions in blood glucose concentration for the two doses of the extracts were higher compared to that of the standard anti-diabetic drug, $0.2 \mathrm{mg} / \mathrm{kg}$ glibenclamide (30.3\%) which served as the positive control

Significant anti-diabetic activities $(\mathrm{P}<0.05)$ were exhibited at 6 and $12 \mathrm{~h}$ for the two different doses of HE respectively.

Table 5. Effect of N-Hexane Extract (HE) of A. Vogelli in Alloxan Induced Diabetic Rats.

Fasting Blood Glucose Concentration (mg/dl)

\begin{tabular}{|c|c|c|c|c|c|c|c|c|c|}
\hline $\begin{array}{l}\text { Gro } \\
\text { up }\end{array}$ & $\begin{array}{c}\text { Treatmen } \\
\mathbf{t}\end{array}$ & $\mathbf{O} \mathrm{h}$ & $0.5 \mathrm{~h}$ & $1 \mathrm{~h}$ & $2 \mathrm{~h}$ & $3 \mathrm{~h}$ & $4 \mathrm{~h}$ & $6 \mathrm{~h}$ & $12 \mathrm{~h}$ \\
\hline 5 & $\begin{array}{c}200 \\
\mathrm{mg} / \mathrm{kg} \mathrm{HE} \\
\text { extract }\end{array}$ & $\begin{array}{c}315.25 \\
\pm 196.07\end{array}$ & $\begin{array}{c}321.25 \\
\pm 195.98 \\
(-1.9 \%)\end{array}$ & $\begin{array}{c}305.75 \\
\pm 202.18 \\
(3.0 \%)\end{array}$ & $\begin{array}{c}240.25 \\
\pm 188.53 \\
(23.8 \%)\end{array}$ & $\begin{array}{c}252.7 \\
\pm 179.12 \\
(19.8 \%)\end{array}$ & $\begin{array}{c}231.75 \\
\pm 153.9 \\
(26.5 \%)\end{array}$ & $\begin{array}{c}183.75 \\
\pm 132.09 * \\
(41.7 \%)\end{array}$ & $\begin{array}{c}137.25 \\
\pm 86.80 * \\
(56.5 \%)\end{array}$ \\
\hline 6 & $\begin{array}{c}400 \\
\mathrm{mg} / \mathrm{kg} \mathrm{HE} \\
\text { extract }\end{array}$ & $\begin{array}{l}322.75 \\
\pm 77.14\end{array}$ & $\begin{array}{c}381.25 \\
\pm 130.42 \\
(-18.13 \%)\end{array}$ & $\begin{array}{c}342.25 \\
\pm 121.61 \\
(-6.0 \%)\end{array}$ & $\begin{array}{c}328.75 \\
\pm 103.03 \\
(-1.9 \%)\end{array}$ & $\begin{array}{c}349.00 \\
\pm 105.40 \\
(-8.1 \%)\end{array}$ & $\begin{array}{c}327.2 \\
\pm 101.01 \\
(-1.39 \%)\end{array}$ & $\begin{array}{c}305.75 \\
\pm 94.71 * \\
(5.3 \%)\end{array}$ & $\begin{array}{l}182.00 \pm \\
116.56 * \\
(43.6 \%)\end{array}$ \\
\hline 7 & $\begin{array}{l}\mathrm{C}_{2 \mathrm{ml} / \mathrm{kg}} \\
\text { olive oil }\end{array}$ & $\begin{array}{c}417.50 \pm \\
204.56\end{array}$ & $\begin{array}{c}419.50 \pm \\
202.49 \\
(-0.5 \%)\end{array}$ & $\begin{array}{c}423.00 \pm \\
208.97 \\
(-1.3 \%)\end{array}$ & $\begin{array}{c}413.75 \pm \\
214.95 \\
(0.9 \%)\end{array}$ & $\begin{array}{c}402.00 \pm \\
224.16 \\
(3.7 \%)\end{array}$ & $\begin{array}{c}431.00 \pm \\
231.74 \\
(-3.2 \%)\end{array}$ & $\begin{array}{c}429.25 \pm \\
214.67 \\
(-2.8 \%)\end{array}$ & $\begin{array}{c}390.25 \pm \\
233.10 \\
(6.5 \%)\end{array}$ \\
\hline
\end{tabular}

c: Control group; Results are expressed as mean \pm SEM $(n=4) ; * p<0.05$, as compared with control group at the same time. One-way, ANOVA followed by Dunnet's t-test; Figures in parenthesis denote percentage reduction of blood glucose. 


\section{DISCUSSION}

High extraction yield of the stem bark of Anthocleista vogelii was obtained but with the methanol solvent. This is likely due to more polar nature of methanol compared to n-hexane as it was able to extract more of the plant constituents. The low extraction yield of HE was the reason we focused on its hypoglycemic effect on the alloxan-induced diabetic rats as that is the major aim of the study.

The effect of the methanol extract showed a dose dependent reduction in the Fasting Blood Glucose (FBG) concentration in the normo glycemic rats which was higher compared to the standard drug, glibenclamide which also has glucose lowering effect in normal animals. Glibenclamide, a known sulphonyurea, was used as the standard in the present study because it has been widely accepted as a standard drug in diabetic animal experiments associated with mild or moderate hyperglycaemia [14]. In the alloxan-induced diabetic category, the methanol and n-hexane extracts of stem bark of Anthocleista vogelii caused significant reductions in blood glucose concentrations. However, the methanol extract had significant antidiabetic activity at the $400 \mathrm{mg} / \mathrm{kg}$ dose from the 0 to 12 th hour unlike the n-hexane extract that had significant activity at the $200 \mathrm{mg} / \mathrm{kg}$ dose.

Alloxan monohydrate at a single dose of $150 \mathrm{mg} / \mathrm{kg}$ was used to induce diabetes in the animals to elevate the FBG to $200 \mathrm{mg} / \mathrm{dL}$. It is a known diabetogenic that acts selectively in two ways; it selectively inhibits glucose-induced insulin secretion through its ability to specifically inhibit the glucokinase, the glucose sensor of the beta cell, and it causes a state of insulin-dependent diabetes mellitus through its ability to induce a selective necrosis of the beta cells [15]. Phytochemical analysis of the methanol and n-hexane extracts revealed the presence carbohydrates, alkaloids, tannins, flavonoids, steroids, saponins, terpenoids, resins and oils in varied proportions. Glycosides were only present in the methanol extract. The presence of these active biological principles especially alakaloids, flavonoids and terpenoids in high concentration in the Anthocleista vogelli stem bark extracts might be responsible for the oral hypoglycaemic effects recorded in the present study. Previous studies have shown that the presence of flavonoids in plants helps in the reduction of fasting blood glucose concentration since flavonoids have been found to stimulate the secretion of insulin [14].The possible mechanism of action might be via the following mechanisms; stimulation of the pancreatic beta cells to secrete insulin, improvement of insulin sensitivity [16], slowing down absorption of carbohydrate and hence slows down glucose production [17]. Hence the higher percentage reduction by the $400 \mathrm{mg} / \mathrm{kg}$ of $\mathrm{ME}$ can be attributed to its high alkaloid and flavonoid contents compared to the $\mathrm{n}$-hexane extract.

\section{CONClusion}

The methanol and n-hexane extracts of the stem bark of Anthocleista vogelii showed potential antidiabetic activities which were dose and non-dose dependent respectively. However, the methanol extract had greater anti-diabetic effect when compared to the $\mathrm{n}$-hexane extract.

Their hypoglycemic effects may be attributed to their flavonoid and alkaloid contents which have been established to be anti-diabetic in previous studies.

Further works aimed at isolation of the flavonoid and alkaloid contents, characterization of active compounds and possible modifications in the structural active compounds of Anthocleista vogelii would be necessary.

\section{ACKNOWLEDGEMENT}

Mr. \& Mrs. Sunday Onyekere for the financial support granted during the work. Department of Pharmaceutical and Medicinal Chemistry, University of Nigeria, Nsukka.

\section{REFERENCES}

[1] Katerere, D.R. and J.N. Eloff, 2005. Management of Diabetes in African Traditional Medicine. In: Traditional Medicines for Modern Times: Antidiabetic Plants, Soumyanath, A. (Ed.)., CRC Press, Boca Raton, FL., ISBN-13: 9781420019001, pp: 203-218.

[2] Balde, N., A. Youla, M.D. Balde, A. Kake, M.M. Diallo, M.A. Balde and D. Maugendre, 2006. Herbal medicine and treatment of diabetes in Africa: An example from Guinea. Diabetes Metab., 32: 171-175. 
[3] American Diabetes Association. Economic consequences of diabetes mellitus in the U.S. in 1997. Diabetes Care 1998; 21(2):296-309.

[4] Kasper DL, Braunwald E, Fauci AS, Hauser SL, Longo DL, Jameson JL ,Editors. 2005. Harrison Principles of Internal Medicine Vol 2 16th Edn Newyork McGraw Hill 2152-79.

[5] Shaw JE, Sicree RA, Zimmet PZ. 2010. Global estimates of the prevalence of diabetes for 2010 and 2030. Diabetes Research and Clinical Practice. ; 87:4-14.

[6] Osadebe, P.O., P.F. Uzor., E.O. Omeje., M.O. Agbo and W.O. Obonga, 2014. Hypoglycemic activity of the extract and fractions of Anthocleista vogelii (Planch) Stem Bark. Trop. J. Pharm. Res., 13: 1437-1443.

[7] Keay RWJ, Onochie CFA, Stanfield FDP. 1964. Nigerian trees. Ibadan, Nigeria: Federal Department of Forest Research.

[8] Sunday Rita. M, IlesanmiOlapade R. and ObuotorEfere M.. 2016. Anti-Diabetic Effect of Anthocleista vogelii Ethanolic Root Extract in Alloxan-Induced Diabetic Rats. Research Journal of Medicinal Plant 10 (1): 79-88.

[9] Jegede, I.A., J.A. Ibrahim and O.F. Kunle, 2011. Phytochemical and pharmocognostic studies of the leaf and stem-bark of Anthocleista vogelii (Planch). J. Med. Plants Res., 5: 6136-6139

[10] Harborune, J. B. 1998. Textbook of Phyto chemical Methods: A Guide to Modern Technique of Plant Analysis. Chapman and hall Ltd: London p12.

[11] Trease, G. E. and Evans, W. C. 1994. Textbook of Pharmacognosy, 13th ed., Balliere Tindall, London, pp. 167-197.

[12] Lenzen, S. and R. Munday, 1991. Thiol-group reactivity, hydrophilicity and stability of alloxan, its reduction products and its N-methyl derivatives and a comparison with ninhydrin. Biochem. Pharmacol., 42: 1385-1391.

[13] Okokon, J.E. and P.A. Nwafor, 2009. Antiplasmodial activity of root extract and fractions of Croton zambesicus. J. Ethnopharmacol., 121: 74-78.

[14] Owolabi, O.J., F.C. Amaechina and M. Okoro, 2011. Effect of ethanol leaf extract of Newbouldalaevis on blood glucose levels of diabetic rats. Trop. J. Pharm. Res., 10: 249-254.

[15] Mythili, M.D., R. Vyas, G. Akila and S. Gunasekaran, 2004. Effect of streptozotocin on the ultrastructure of rat pancreatic islets. Microsc. Res. Tech., 63: 274-281.

[16] Bosenberg, L.H. and D.G. Van Zyl, 2008. The mechanism of action of oral antidiabetic drugs: A review of recent literature. J. Endocrinol. Metab. Diabetes South Afr., 4: 80-88.

[17] Kruger, D.F. and M.A. Gloster, 2004. Pramlintide for the treatment of Insulin-requiring diabetes mellitus. Drugs, 64: 1419-1432. 